\title{
細粒分を含む砂質土の相対密度 および液状化強度評価に関する検討
}

\author{
中澤 $\quad$ 博志 1 ・原田 健二 $2^{2}$ \\ 1正会員 復建調査設計株式会社 東京支社（前港湾空港技術研究所 而震構造研究チーム） \\ （干101-0032 東京都千代田区岩本町3-8-15） \\ E-mail: nakazawa@fukken.co.jp \\ 2正会員＼cjkstart不動テトラ株式会社＼cjkstart地盤事業本部（テ113-0016 東京都中央区小網町7-2） \\ E-mail: kenji.harada@fudotetra.co.jp
}

\begin{abstract}
細粒分を多く含む砂の液状化について，1987年千葉県東方沖地震での液状化の発生を契機に検討され始 めた。一般に, 細粒分含有率あるいは塑性指数の増加に伴い液状化強度が増大寸るといわれているが, 幾 つかの既往の研究によると, 細粒分含有率の值によっては供試体の相対密度が大きく異なり, 同一条件下 における液状化強度が評価されていないようである。したがって, 本論文では, 細粒分含有率が $5 \%$ 以下 であるきれいな砂からシルトを対象とした幅広い粒度特性を有する地盤材料を対象に, 最大・最小間隙比 幅に着目した細粒分を含む砂の相対密度の補正方法および補正された相対密度と液状化強度との関係につ いて検討した。一連の検討から, 細粒分含有率が $15 \%$ 以上における相対密度の補正方法の提案および補正 相対密度と液状化強度の関係から，液状化強度に対する細粒分含有率の影響について示すことができた。
\end{abstract}

Key Words : liquefaction strength, relative density, fine sand, fine content, minimum void ratio

\section{1. はじめに}

1964 年に起こった新潟地震以来，細粒分を含まない きれいな砂を対象として地盤の液状化の研究が行われて きた。しかし，その後の被災事例より，細粒分を含む砂 や砶質土，あるいは埋立地のまさ土や低塑性のシルトと いった様々な地盤材料に関しても液状化することが指摘 され，研究の対象が広がってきた。

細粒分を多く含む砂の液状化については，1987 年千 葉県東方沖地震での液状化の発生を契機として検討され, その後も2000 年鳥取県西部地震に発生した低塑性のシ ルトによる大規模な液状化の事例も確認されている. 一 般に, 細粒分含有率の増加に伴い液状化強度が増大寸る

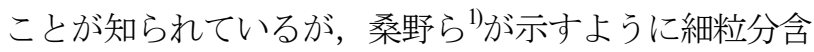
有率がある程度大きくなると, 試料の塑性指数の值によ っては，Rlにばらつきが見られるようになる，また，細 粒分含有率の值によっては供試体の密度が大きく異なり， 同一密度における細粒分含有率の液状化強度への影響に ついて検討することが困難なことから，単なる液状化強 度の評価のみならず，締固め系の地盤改良効果の判定等 も難しくしていると考えられる.

このような問題に対し，本論文では，最大・最小間隙
比と液状化強度の関係に着目し，これらのデータを既往 の研究結果を基に，細粒分含有率が5\%以下であるきれ いな砂から低塑性のシルト質砂やシルト等，様々な試料 の物理的性質についてまとめ, 細粒分を含む砂の相対密 度の補正方法についてまとめた。また，これに基づき， 既往の液状化強度の推定方法を参考に，細粒分を含む試 料の最大 ・最小間隙比から液状化強度の推定式について 検討し，同一相対密度において，細粒分含有率が液状化 強度へ与える影響について報告する。

\section{2. 液状化強度に関する既往の研究}

（1）砂の相対密度および液状化強度の評価

細粒分含有率 $F_{c}$ が $5 \%$ 以下であるきれいな砂の液状化 強度に関しては，豊浦砂や新潟砂を始め, 数多くの研究 がなされている. Ishihara et al. $^{2}$ は，繰返し三軸試験から 得られる液状化強度 $R_{I}$ (繰返し載荷回数 $N_{c}=20$ 回, 軸 ひずタ両振幅 $D A=5 \%$ ）が相対密度 $D_{r}$ に対しほぼ比例 関係が成り立つとして，次式を与えている。

$$
R_{l}=0.0042 D_{r}
$$


また，Tatsuoka et al. ${ }^{3)}$ は，豊浦砂の繰返しねじりせん断 試験を実施し，液状化強度と相対密度の関係は， $D_{r} \geqq$ $80 \%$ の範囲では液状化強度が増大寸る傾向を見せること から，式(1)は $D_{r}$ が 80\%の以下の範囲で成り立つ関係で あることや，細粒分を多く含む砂に関しては成り立たな いことを指摘している ${ }^{4)}$ 。また，式(2)で表される Meyerhof ${ }^{\text {の} の ~} N$ 值と $D_{r}$ の関係式を用い，式(1)に代入する ことで式(3)に示す液状化強度 $R_{l}$ と $N$ 值の関係を得てい る.

$$
\begin{aligned}
& D_{r}=21 \sqrt{\frac{N}{\sigma_{v}{ }^{\prime} / 98+0.7}} \\
& R_{l}=0.0882 \sqrt{\frac{N}{\sigma_{\mathrm{v}}{ }^{\prime} / 98+0.7}}
\end{aligned}
$$

ここに， $\sigma_{v}^{\prime}$ は有効土被り圧を示す.さらに，式(1)につ いて, 広範囲な粒径まで対応させ, 平均粒径 $D_{50}$ による 補正項を提案している.

一方, Tokimatsu and Yoshimi'も原位置凍結サンプリン グ試料により，密な砂の $D_{r}$ と $R_{l}$ の関係について検討を 行い， $D_{r}$ が $80 \%$ を超える場合における $R_{l}$ の急増傾向に ついて，式(4)により表現している.

$$
R_{l}=a\left[\frac{D_{r}}{100}+\left(\frac{D_{r}}{C}\right)^{n}\right]
$$

ここに，a，n は実験定数， $C=97-\log (D A) （=83.7 ） ， お$ よび $D A$ は軸ひず夕両振幅(\%)を示す。また，細粒分を多 く含む砂の $R_{l}$ について，式(5)に示すように，実測 $N$ 值 に細粒分の影響を補正する項 $\Delta N_{f}$ を加えた $D_{r}$ を用いるこ とで， $R_{l}$ の補正方法について提案している.

$$
D_{r}=21 \sqrt{\frac{N}{\sigma_{v}^{\prime} / 98+0.7}+\frac{\Delta N_{f}}{1.7}}
$$

\section{（2）細粒分を含む砂の液状化強度特性}

細粒分を多く含む砂の液状化に関しては，1987年千葉 県東方沖地震以来，多くの事例が報告されている7-13). いずれも細粒分が非常に多い砂質土の場合， $F_{c}$ の増加に 伴いRが増大寸ることが示されている．しかし，マトリ クスの構成粒子の特性によっては， $F_{c}$ がある程度大きく なると，Rにばらつきが見られることが報告されている 8)。また，桑野ら ${ }^{10)}$ は，細粒分の影響を評価する物理的

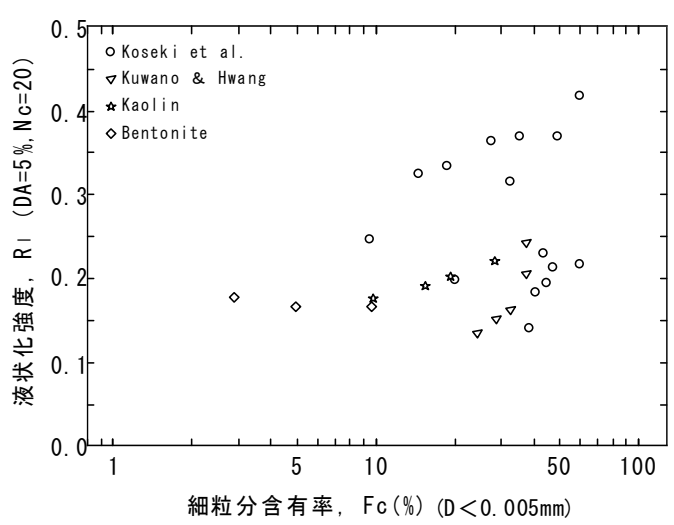

(a) 細粒分含有率と液状化強度の関係

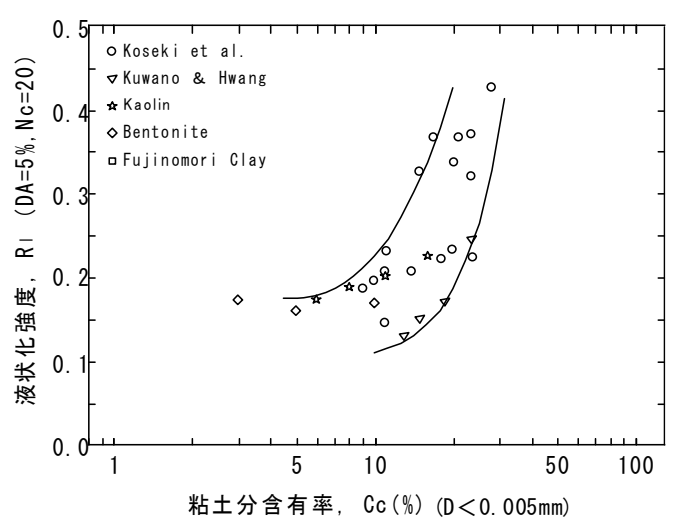

(b) 粘土分含有率と液状化強度の関係

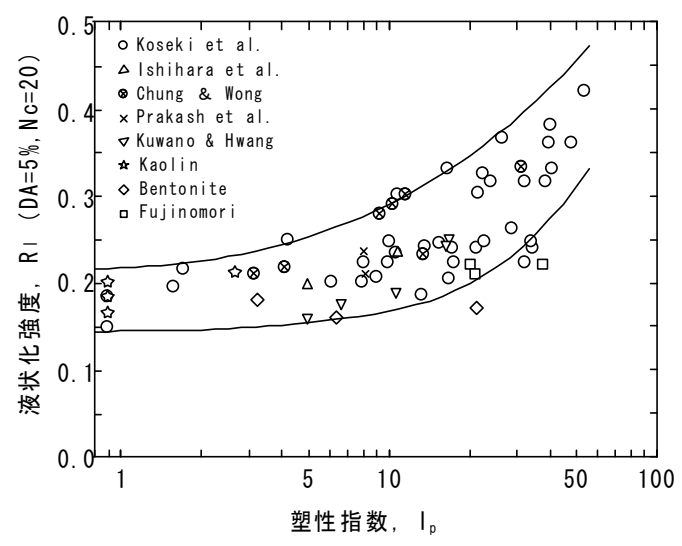

(c) 塑性指数と液状化強度の関係

図-1 細粒分を含む砂の液状化強度特性（参考文献 ${ }^{9}$ をを修正 加筆)

指標として，粘土分含有率 $C_{c}$ や塑性指数 $I_{p}$ を用い， $R_{l}$ と の関係を図-1のようにまとめている．特に， $F_{c}$ とR, 関 係において， $F_{c}$ の増加に伴う $R_{l}$ の単調増加が確認できる が，それらの関係は，地盤材料の違いにより異なる傾向 を示している．次に， $C_{c}$ とR $R_{l}$ 関係を見ると， $C_{c}$ が $10 \%$ 以上の範囲ではR,が急増する傾向を示し，地盤材料の違 いの影響が少ない様子がわかる. 一方， $I_{p}$ とR の関係で は， $I_{p}$ が小さい範囲では，R/ $R_{l}$ ばらつきが少ないものの， $I_{p}$ の值が 10 程度を超える範囲からRが増大し，同時にば 
表-1＼cjkstart検討データ一覽

\begin{tabular}{|c|c|c|c|c|c|c|c|c|c|c|c|c|}
\hline & 試 & $\begin{array}{c}\text { 細粒分含有率 } \\
F_{c}(\%)\end{array}$ & $\begin{array}{c}\text { 相対密度 } \\
D_{r}(\%)\end{array}$ & $\begin{array}{c}\text { 最小間隙比 } \\
e_{\min }\end{array}$ & $\begin{array}{c}\text { 最大間隙比 } \\
e_{\max }\end{array}$ & $\begin{array}{l}\text { 平均粒径 } \\
D_{50}(\mathrm{~mm})\end{array}$ & $\begin{array}{c}\text { 均等係数 } \\
U_{c}\end{array}$ & $\begin{array}{c}\text { 塑性指数 } \\
I p \\
I p\end{array}$ & $\begin{array}{c}\text { 液状化強度 } \\
R_{l}\end{array}$ & $N$ 值 & 供試体の条件 & 参考文献 \\
\hline 1 & 豊浦砂 & 0.0 & $40 \sim 70$ & 0.609 & 0.968 & 0.180 & 1.67 & NP & $0.108 \sim 0.327$ & - & AP & 17) \\
\hline 2 & 相馬砂ほか & $\geqq 5.0$ & $40 \sim 70$ & 0.659 & 1.028 & $0.25 \sim 0.56$ & $1.35 \sim 2.50$ & NP & $0.123 \sim 0.245$ & - & $\mathrm{AP}$ & 18) \\
\hline 3 & Quarts sandほか & $0 \sim 28$ & $55 \sim 95$ & 0.603 & 1.213 & $0.065 \sim 0.19$ & $2.70 \sim 20.0$ & NP & $0.130 \sim 0.255$ & - & AP & 19) \\
\hline 4 & 袖ケ浦町の噴砂ほか & $3 \sim 97.2$ & $33 \sim 64$ & 0.692 & 1.172 & $0.028 \sim 0.14$ & $1.50 \sim 5.20$ & $3.4 \sim 9.1$ & $0.112 \sim 0.126$ & - & AP & 20) \\
\hline 5 & $\begin{array}{l}\text { カオリン混じり豊浦 } \\
\text { 砂 }\end{array}$ & $0 \sim 80$ & $22.5 \sim 157.1$ & $0.602 \sim 1.359$ & $0.985 \sim 2.456$ & $0.063 \sim 0.180$ & $1.667 \sim 21.4$ & $\mathrm{NP} \sim 39.6$ & $0.072 \sim 0.133$ & - & AP & 21) \\
\hline 6 & $\begin{array}{l}\text { 藤森粘土混じり豊浦 } \\
\text { 砂 }\end{array}$ & $0 \sim 40$ & $65.0 \sim 102.4$ & $0.695 \sim 0.890$ & $1.275 \sim 1.770$ & $0.105 \sim 0.170$ & $1.82 \sim 70.0$ & $\mathrm{NP} \sim 14.3$ & $0.112 \sim 0.180$ & - & $\mathrm{AP}$ & 22) \\
\hline 7 & 相馬硅砂（5号硅砂） & 0.8 & $46.9 \sim 55.1$ & 0.685 & 1.105 & 0.347 & 1.88 & NP & 0.115 & - & $\mathrm{AP}$ & - \\
\hline 8 & 石狩砂 & $2.0 \sim 29.4$ & $17.8 \sim 94.9$ & $0.853 \sim 0.871$ & $1.307 \sim 1.488$ & $17.8 \sim 94.9$ & $1.90 \sim 10.0$ & NP & $0.171 \sim 0.367$ & $1 \sim 22$ & AP, UD & 23) \\
\hline 9 & 新潟砂 & $\geqq 5.0$ & $45 \sim 53$ & 0.655 & 1.005 & $0.230 \sim 0.370$ & $1.67 \sim 2.34$ & NP & $0.190 \sim 0.24$ & $3 \sim 37$ & AP, UD & 24) \\
\hline 10 & 新潟砂他 & $0.0 \sim 5.8$ & $26 \sim 115$ & - & - & $0.200 \sim 0.490$ & $0.23 \sim 2.10$ & $\mathrm{NP}$ & $0.130 \sim 0.91$ & $1 \sim 31$ & $\begin{array}{l}\text { UD (凍結含 } \\
\text { 屯) }\end{array}$ & 25) \\
\hline 11 & 竹内シルト & $89.1 \sim 98.7$ & $65 \sim 100$ & 0.287 & 0.614 & $0.031 \sim 0.046$ & $2.38 \sim 3.25$ & $\mathrm{NP} \sim 21.5$ & 0.132 & $1 \sim 4$ & UD & 26) \\
\hline 12 & 越谷砂 & 0.8 & 65 & 0.771 & 1.064 & 0.260 & 2.73 & NP & 0.153 & $3 \sim 12$ & UD & 27) \\
\hline 13 & 曙橋砂 & $2.3 \sim 45.0$ & $24.6 \sim 82.0$ & $0.582 \sim 0.738$ & $1.224 \sim 1.443$ & $0.09 \sim 0.16$ & - & NP & $0.150 \sim 0.215$ & $2 \sim 12$ & UD (凍結) & 28) \\
\hline 14 & 梅田砂 & $10.0 \sim 33.0$ & $70.5 \sim 96.9$ & 0.877 & 1.551 & $0.110 \sim 0.140$ & $2.60 \sim 73.1$ & NP & $0.215 \sim 0.260$ & $2 \sim 4$ & UD & 29) \\
\hline 15 & 入谷砂 & $16.8 \sim 20.8$ & $71.6 \sim 88.9$ & 0.808 & 1.427 & $0.170 \sim 0.240$ & $5.0 \sim 53.0$ & NP & $0.35 \sim 0.57$ & $3 \sim 12$ & UD & 29) \\
\hline 16 & アダパザルシルト & $75.1 \sim 99.7$ & $91.4 \sim 119.6$ & 1.000 & 1.909 & $0.014 \sim 0.051$ & $2.59 \sim 7.87$ & $5.4 \sim 38.4$ & $0.25 \sim 0.55$ & - & UD & 30) \\
\hline 17 & 沖積砂質土 & $15 \sim 31$ & $69.4 \sim 107.4$ & $0.694 \sim 1.004$ & $1.052 \sim 1.658$ & $0.132 \sim 0.271$ & - & - & $0.27 \sim 0.45$ & $0 \sim 21$ & UD & 31) \\
\hline 18 & 沖積砂質土 & $0.5 \sim 96.0$ & $18.2 \sim 156.0$ & $0.496 \sim 1.030$ & $0.759 \sim 1.830$ & $0.004 \sim 2.5$ & $1.60 \sim 303$ & - & $0.154 \sim 0.750$ & $1 \sim 39$ & UD & 32) \\
\hline 19 & 相馬港他 & $7.7 \sim 65.9$ & - & $0.662 \sim 1.000$ & $1.286 \sim 1.525$ & $0.036 \sim 0.402$ & $9.0 \sim 51.4$ & NP & $0.130 \sim 0.380$ & $2 \sim 6$ & UD & 23) \\
\hline 20 & $\begin{array}{l}\text { 日本海中部地震液状 } \\
\text { 化被害地域 }\end{array}$ & $0.3 \sim 100$ & $21.0 \sim 130.7$ & - & - & $0.003 \sim 0.480$ & - & - & $0.148 \sim 0.520$ & $1 \sim 29$ & UD & 33) \\
\hline 21 & 釧路港砂他 & $0 \sim 78$ & $30.7-82.1$ & - & - & $0.046 \sim 0.730$ & $1.5 \sim 9.6$ & - & $0.192 \sim 0.345$ & $3 \sim 24$ & UD & 34) \\
\hline
\end{tabular}

らつきが多く見られる様子がわかる．このように，細粒 分を含む砂のR

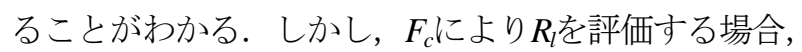
供試体の密度の影響を評価していない場合が多く，供試 体の密度を考慮した $F_{c}$ の影響について統一的に報告され ている事例が少ないことが指摘されている ${ }^{14)}$.

\section{（3）様々な粒度特性を表す物理的指標の評価}

細粒分を含む砂の $D_{r}$ の評価について, Cubrinovski and Ishihara $^{15}$ により，シルトから礫を含む様々なタイプの土 質試料の物理的性質について検討されている. 最大間隙 比 $e_{\text {max }}$ および最小間隙比 $e_{\min }$ の差で表される間隙比幅 $\left(e_{\max }\right.$ $\left.-e_{\text {min }}\right)$ が， $D_{50}$ および $F_{c}$ と相関が高いことが示され，式 (6), (7)で表されている. なお, $\left(e_{\text {max }}-e_{\text {min }}\right)$ の評価は, $F_{c}$ が $10 \sim 30 \%$ の細粒分混じり砂で $0.5 \leqq\left(e_{\text {max }}-e_{\text {min }}\right)<0.7$, き れいな砂で $0.3 \leqq\left(e_{\text {max }}-e_{\text {min }}\right)<0.5$, および磎質土で $0.2 \leqq$ $\left(e_{\text {max }}-e_{\text {min }}\right)<0.3$ の範囲に区分され, $D_{50}$ が小さいほど, 逆 に $F_{c}$ の増加に伴い $\left(e_{\max }-e_{\min }\right)$ の值が大きくなる.

$$
\begin{aligned}
\left(e_{\text {max }}-e_{\text {min }}\right)=0.230+\frac{0.06}{D_{50}} & \\
\left(e_{\text {max }}-e_{\text {min }}\right)=0.430+0.0086 F_{c} & \left(F_{c}<30 \%\right) \\
= & 0.570+0.0040 F_{c} \quad\left(F_{c}>30 \%\right)
\end{aligned}
$$

$e_{m a x}, e_{m i n}$ を求めるための最小密度・最大密度試験 ${ }^{16}$ は, $D_{r}$ を求めるために必要な試験であるが, 本来, 細粒分含 有率 $F_{c} か ゙ 5 \%$ 以，最大粒径が $2 \mathrm{~mm}$ 以上であると適応範 囲外とされている。試験規格適応範囲外の細粒分が多い 試料では，団粒化等の無視できない要因があり，砂と同 様に最小密度・最大密度試験を実施する場合に問題点は あるのは事実であるが， $D_{r}$ を求めるだけでなく，式(6), (7)に示寸様に地盤材料の物理特性を表現できるパラメ 一タとして, 粒度分布や粒子形状の異なる試料の物理的 性質を客観的に判断できるものと考えられる.

\section{3. 相対密度および液状化強度の評価方法に関す る検討}

種類の異なる地盤材料の $R_{l}$ について, $\left(e_{\text {max }}-e_{\text {min }}\right)$ によ る評価方法について検討する．まずは， $\left(e_{\max }-e_{\min }\right), F_{c}$ および $D_{r}$ 等の地盤材料の物理的性質と液状化強度につ いてデータを既往の研究より収集し，これらのデータを 基に， $F_{c}$ が $5 \%$ 以下であるきれいな砂から低塑性のシル 卜質砂を対象とした相対密度の再評価を目的とした検討 を行った. 表-1 に収集したデータの取りまとめを示す. なお，表中の AP は空中落下法による再構成試料を意味 し，UD は凍結サンプリング試料を含む不擋乱試料を示 している. 


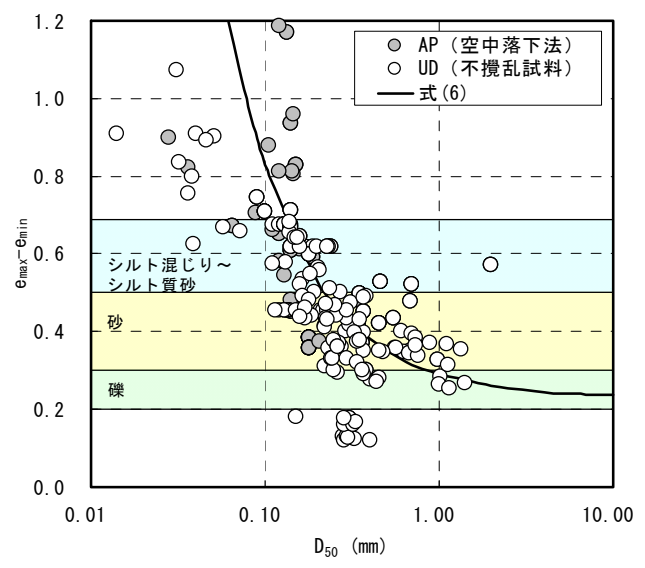

図-2 平均粒径と間隙比幅の関係

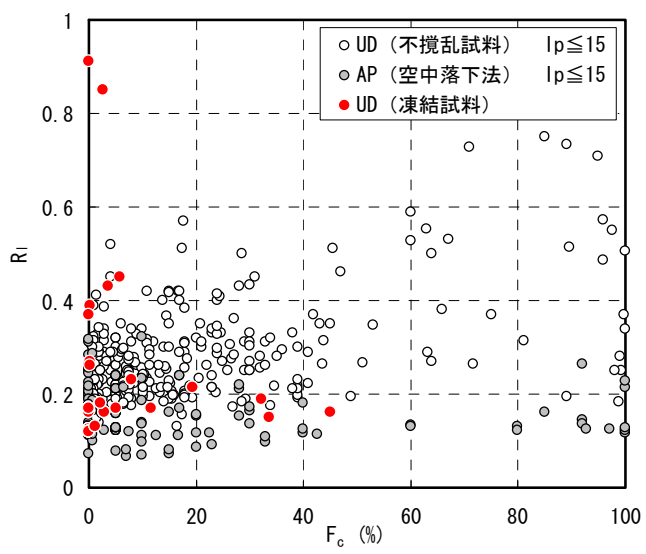

図-4 細粒分含有率と液状化強度の関係

\section{（1）物理的性質}

表-1 に示すデータは， $F_{c}$ が $0 〜 100 \%$ の広範囲に分布 し， $D_{r}$ についても概ね 20\%〜100\%を超える再構成試料 および不撹乱試料を含む緩い〜密な供試体の試験結果が まとめられている.

次に, $\left(e_{\max }-e_{\min }\right)$ と $D_{50}$ および $F_{c}$ の関係について, 図-2 および図-3 にそれぞれ示す。なお，これらの図中

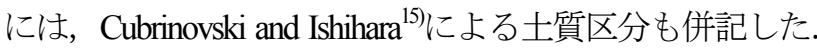
図-2 に示す $\left(e_{\max }-e_{\min }\right)$ と $D_{50}$ の関係については, 式(6) の関係に対し，比較的良い相関を示している。 また, 図-3 に示す $\left(e_{\max }-e_{\min }\right)$ と $F_{c}$ の関係については, 式(7) に比べ, $F_{c} \geqq 20 \%$ の範囲において $\mathrm{AP} の ~\left(e_{\max }-e_{\min }\right)$ が大 きな分布を示しているものの, UD に関しては良く一致 していることがわかる.

\section{（2）細粒分含有率と液状化強度の関係}

表-1 に示寸試験結果について， $I_{p} \leqq 15$ を対象とした $F_{c}$ と $R_{l}$ の関係を図-4 に示す. AP，UD ともにプロット のばらつきが大きいが，AP の傾向として， $F_{c}$ の増加に 伴い，10\%程度まで $R_{l}$ はやや減少傾向にあり， $F_{c}$ が $10 \%$

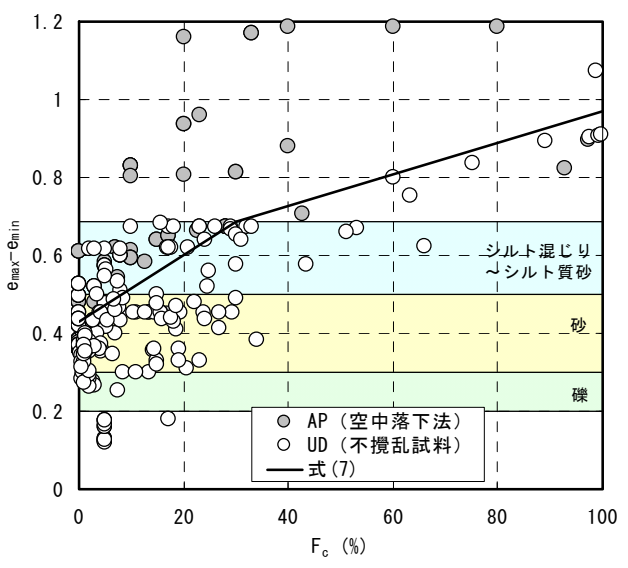

図-3 細粒分含有率と間隙比幅の関係

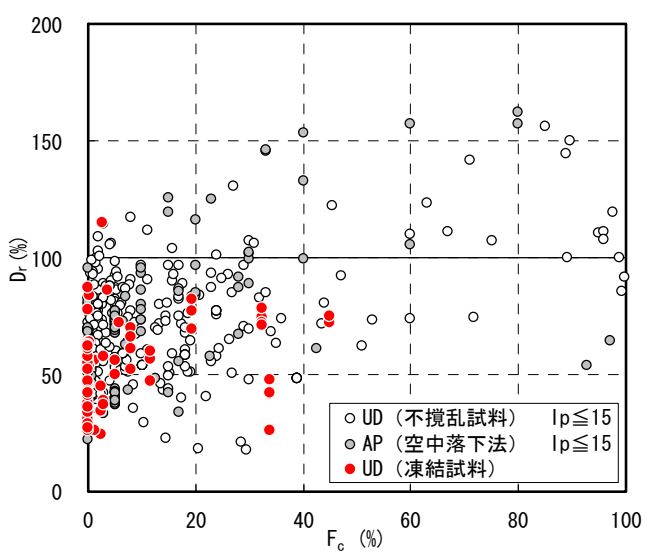

図-5 細粒分含有率と相対密度の関係

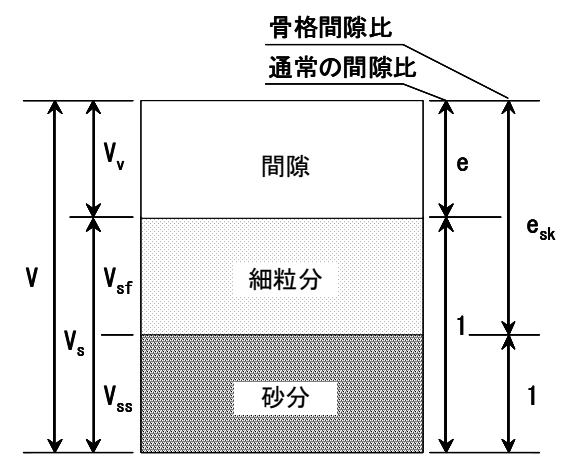

図-6＼cjkstart砂の配合に関する模式図

を超えると再び微増に転じているか，または横ばいを示 している. 一方, UD については, $F_{c}$ の増加に伴い, $R_{l}$ が単調増加傾向にあることがわかる．また，凍結試料に ついては，細粒分がある程度含まれた状態では，APと 同様な $R_{l}$ の分布傾向を示しているが，凍結による試料 の乱れ等の影響があったものと推察される.

次に, 図-5 に示す $F_{c}$ と $D_{r}$ の関係を見ると, 特に AP では， $F_{c}$ が概ね 15～40\%の範囲を超えると $D_{r} \geqq 100 \%$ を 


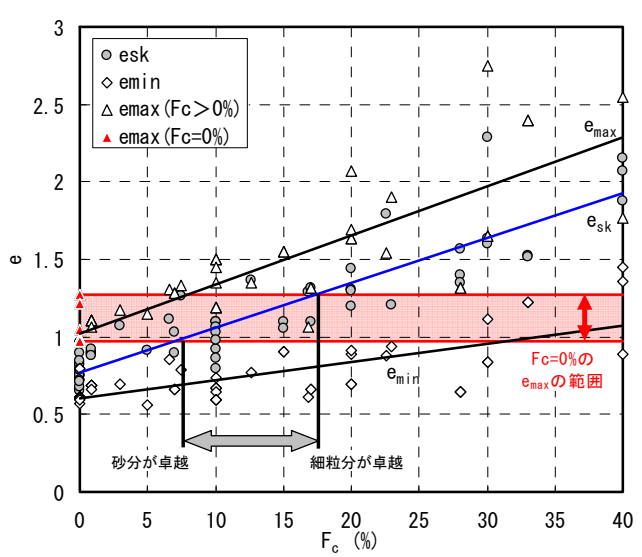

(a) AP (空中落下法)

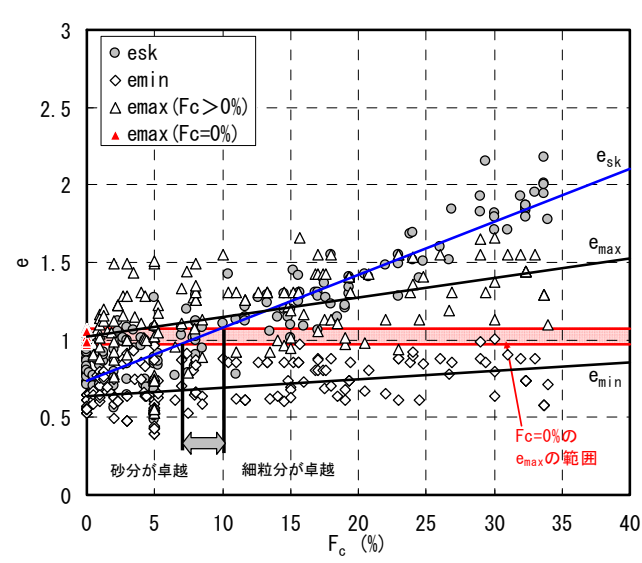

(b) UD (不攪乱試料)

図-7 細粒分含有率と骨格間隙比の関係

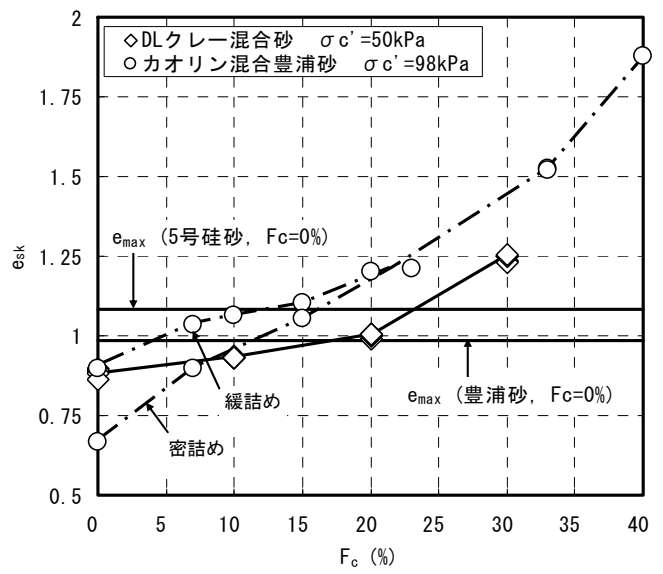

図-8＼cjkstart細粒分含有率と骨格閒隙比の関係

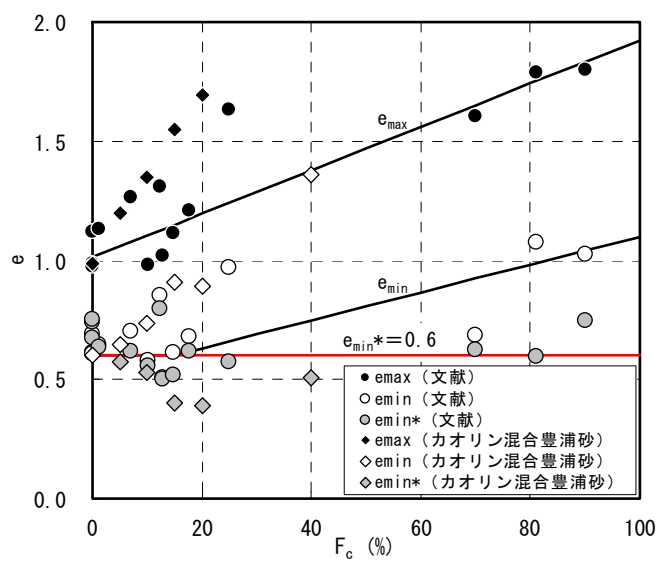

図-9＼cjkstart細粒分含有率と最大・最小間隙比の関係
示している様子がわかる. 一方，UDについては $F_{c}$ の増 加に伴い $D_{r}$ も増加傾向を示し， $F_{c}$ が全般的に $D_{r} \geqq 100 \%$ を示すプロットが存在するが，凍結試料では，特に増加 傾向は確認できないことがわかる.

ここで，細粒分も間隙と見なす骨格間隙比 $e_{\mathrm{sk}}$ の概念 を用い， $F_{c}$ と $e_{s k}$ の関係を検討する. 細粒分を含む砂の 骨格構造に関しては，既往の研究 ${ }^{37), 38)}$ より，土の構造が 粗粒土が主体的に骨格を形成する場合と細粒分が主体的 で土要素全体が圧縮性を有する場合に分けて考えること が出来る. 図-6に混合土の模式図を示す。通常の間隙 比 $e$ は式(8)で示されるが， $e_{s k}$ は，土粒子の固体部分を粗 粒子と細粒分に分類し，砂骨格の影響を定量的に表現す るため細粒分を間隙と仮定し，式(9)で示される.

$$
\begin{gathered}
e=\frac{V_{V}}{V_{S}}=\frac{V_{V}}{V_{S S}+V_{S F}} \\
e_{s k}=\frac{V_{V}+V_{S F}}{V_{S}-V_{S F}}=\frac{V_{V}+V_{S F}}{V_{S S}}
\end{gathered}
$$

$F_{c}$ と $e_{s k}$ の関係について図-7 に示す.なお，同図では， $e_{\text {max }}$ について, $F_{c}=0 \%$ と $F_{c}>0 \%$ におけるプロットを分け, $e_{s k}$ と比較するため, $F_{c}=0 \%$ の $e_{\max }$ の分布範囲を赤色の八 ッチング部分で示した。 また，図中の直線は， $e_{\text {max }}, e_{\text {min }}$ および $e_{\mathrm{sk}}$ のすべてのプロットに対する一次の回帰直線 をそれぞれ示している. AP を見ると， $F_{c}$ が 7〜 17\%の範 囲を中心に，UD では概ね 7〜 10\%の範囲を中心として， $e_{\text {sk }}$ が $F_{c}=0 \%$ の時の $e_{\max }$ を上回っている様子がわかる. これは，砂分にある程度の細粒分が含まれると，砂粒子 同士の接触が減少するためであり，この状態よりも $F_{c}$ が増加すると，細粒分の性質が次第に卓越すると考えら れる.

図-8に相馬 5 号硅砂に DLクレーを混合した DL クレ 一混合砂および豊浦砂にカオリンを混合したカオリン混 合豊浦砂の $F_{c}$ と $e_{s k}$ の関係を示す. 同図においても, DL クレー混合砂では $F_{c}$ が $22 \%$ 以上，カオリン混合豊浦砂 では 5 $12 \%$ 程度以上で $e_{s k}$ が $F_{c}=0 \%$ の時の $e_{\text {max }}$ を上回っ ており，図-7に示した傾向と概ね整合する.

上記の検討より，ある特定の $F_{c}$ を境界にして骨格構造 が変化し， $F_{c}$ が小さく砂分の影響が卓越する場合には, 


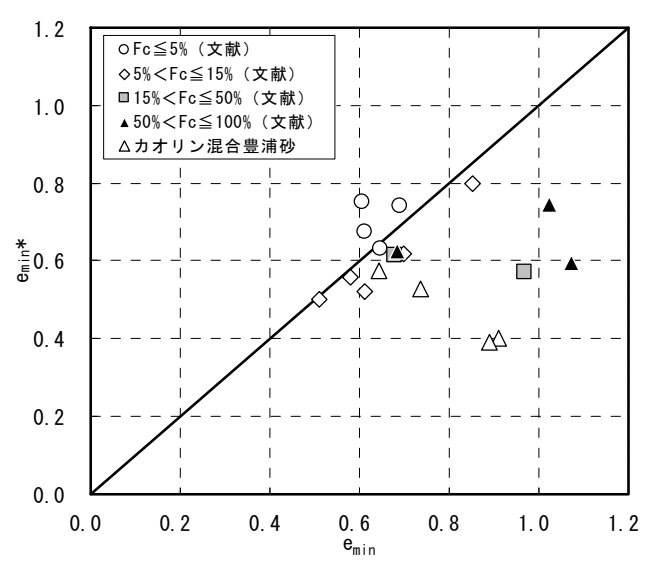

図-10 $e_{\min }$ と $\rho_{\text {dmax }}$ より求めた $e_{\min } *$ の比較

Rlは砂粒子骨格の堆積構造の影響が大きいものと推察さ れる，一方， $F_{c}$ が大きい場合には，砂粒子の骨格構造よ りも細粒分の影響が支配的となり，Rに及ぼす $F_{c}$ の影響

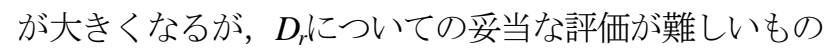
と考えられる.

\section{(3) 細粒砂における相対密度の補正}

図-5 からもわかるように，細粒分を含む砂の $D_{r}$ につ いては，現行の試験規格による最大・最小密度試験によ ると, 過大評価される傾向にあり, $R_{l}$ の評価が困難とな る.この原因は $e_{\text {min }}$ を過小評価するためと考え，物理的 に作り得る最小の間隙比を得るため, 締固め試験（JIS A 1210） ${ }^{37}$ にり得られる $\rho_{\text {dmax }}$ により $e_{\text {min }}{ }^{*}$ を求め, これ により細粒分の影響を考慮した補正相対密度 $D_{r}$ *を求め た.

$D_{r}$ の細粒分補正にあたり，主に参考文献 ${ }^{38)}$ のデータ

(以下，文献值）および別途実施したカオリン混合豊浦 砂の締固め試験結果をまとめ, $F_{c}$ と $e_{\text {max }}, e_{\min }$ および $e_{\min }{ }^{*}$ の関係を図-9 に示寸，なお，参考文献 ${ }^{38)}$ では，細粒砂 における最小の間隙比を得るために, 締固め試験の締固 めエネルギー $E_{c}$ を通常の 8 倍 $\left(8 E_{c}\right)$ として試験を実施 している. 図-9 に示すカオリン混合豊浦砂の $e_{\text {min }}{ }^{*}$ に関 しては, 一般に行われる締固め試験法を踏襲し, 締固め エネルギーは基準のまま, $E_{c}=550 \mathrm{~kJ} / \mathrm{m}^{3}$ として試験を実 施し求めた。ただし， $8 E_{c}$ 以下の締固めエネルギーであ れば，得られる $\rho_{\text {dmax }}$ にあまり変化が無いことが指摘され ており,ここでは, 締固めエネルギーについては議論し ないものとする.

$e_{\text {min }}$ と $e_{\text {min }}{ }^{*}$ 分布を見ると, カオリン混合豊浦砂では, $F_{c}$ が $5 \%$ を超える範囲から両者に差が生じ， $e_{\text {min }}$ が増加し ている様子がわかる。一方，文献值を見ると， $F_{c}$ が $15 \%$ を超える範囲では， $e_{\min }{ }^{*}$ は概ね 0.6 程度の一定值を示し ている. 文献值とカオリン混合豊浦砂による結果の差に ついては粒度特性等の影響があるものと考えられるが,

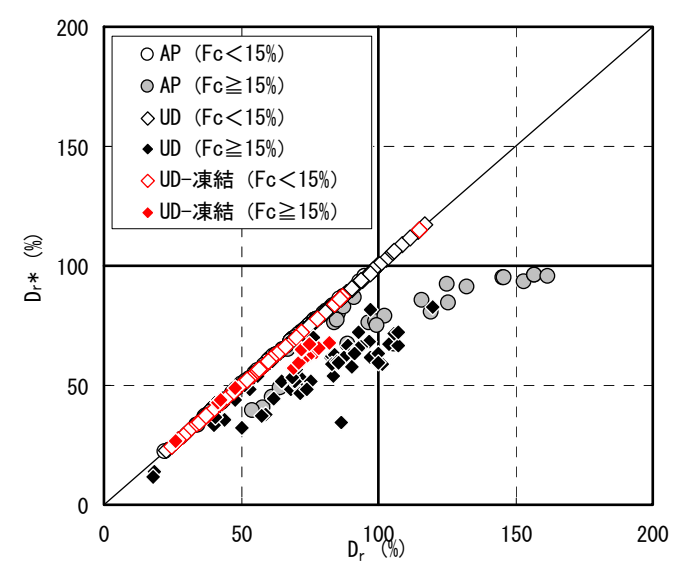

図-11 補正相対密度 $D_{r}^{*}$ の評価

ある $F_{c}$ を超えると細粒分が砂骨格よりも卓越し， $e_{\min }{ }^{*}$ が 概ね一定值に落ち着く点で, 両者の傾向は一致している.

図-10に $e_{\min }$ と $e_{\min }{ }^{*}$ の関係を示し比較すると， $F_{c} \leqq 15 \%$ において，両者は 1:1 のライン付近にプロットされ， 15\%を超えるとばらつきはあるものの， $e_{\text {min }}{ }^{*}$ が小さい範 囲に分布する.

以上の結果より， $D_{r}$ に対する細粒分補正については, $F_{c}>15 \%$ の範囲で $e_{\text {min }}{ }^{*}=0.6$ として $D_{r}^{*}$ 算出することと して， $D_{r}$ と $D_{r}^{*}$ の比較を図-11 に示す．本補正により， $\mathrm{AP}, \mathrm{UD}$ および UD-凍結のいずれも， $D_{r}$ *分布は同様な 傾向を示しており， $D_{r} \geqq 100 \%$ のデータが， $D_{r}^{*}$ *では $100 \%$ 以内に分布し，より現実的な值を示している.

\section{（4）相対密度と液状化強度の関係}

$F_{c}=15 \%$ を補正の閾值として, 図-12 に $D_{r}$ および $F_{c} \geqq$ $15 \%$ 範囲で $e_{m i n}{ }^{*}=0.6$ とした補正相対密度 $D_{r}^{*}$ と $R_{l}$ の関 係を示す．図中には， $F_{c}<5 \%$ における既往の関係式お よび参考文献 ${ }^{25}$ に掲載されている凍結サンプリングとチ ユーブサンプリングによる $N_{1}$ と $R_{l}$ の関係について $N_{1}$ を式(2)により $D_{r}$ に換算し， サンプリング方法の違いに よる $R_{l}$ の傾向について併記した．なお， $F_{c} \leqq 15 \%$ の範囲 では $D_{r}$ の細粒分補正を行わないため， $D_{r}$ および $D_{r}{ }^{*}$ と $R_{l}$ の関係は同一である.

既往の関係式と試験結果を比べると，AP，UD 共に全 体的に $R_{l}$ が低くなっているものの， $F_{c}$ が $15 \%$ を超える 範囲にある $D_{r}^{*}$ と $R_{l}$ の関係は, 細粒分補正によりプロッ 卜のばらつきが減少している様子がわかる. 次に, $F_{c} \leqq 15 \%$ と細粒分補正を行った $F_{c}>15 \%$ のプロットの範 囲を比較すると, AP における細粒分を多く含む $F_{c}>$ $15 \%$ のプロットが， $F_{c} \leqq 15 \%$ の分布範囲の下限付近に位 置している. 一方, UDでは, AP とは逆に $F_{c}>15 \%$ のフ ロットが $F_{c} \leqq 15 \%$ の分布範囲より上位に分布する傾向を 示し， $R_{l}$ がやや大きくなる様子が確認出来る. 両者の傾 向の違いは，図-4 と調和的な傾向を示寸が，AP と UD 


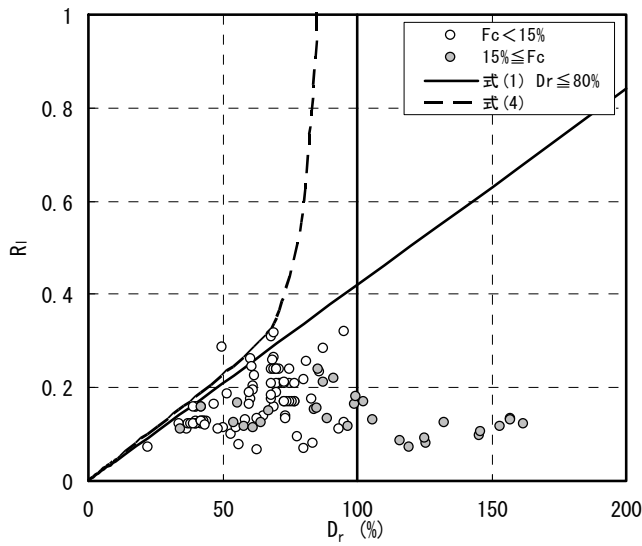

(a) $\mathrm{AP}\left(D_{r}\right.$ 補正無し)

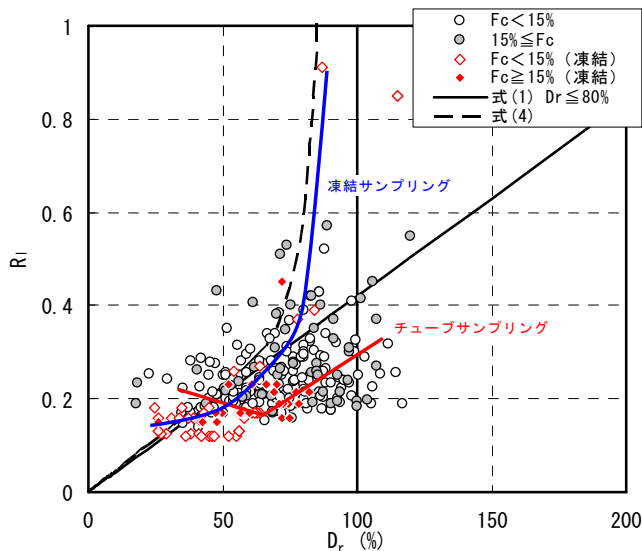

(c) UD ( $D_{r}$ 補正無し)

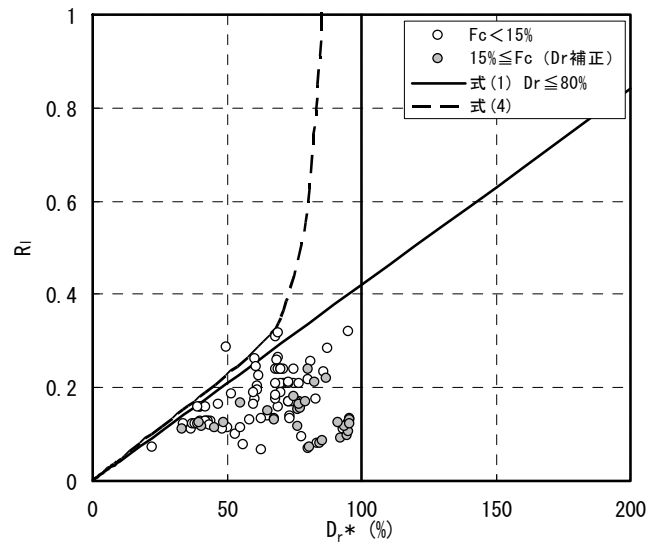

(b) $\mathrm{AP}\left(D_{r}\right.$ 補正)

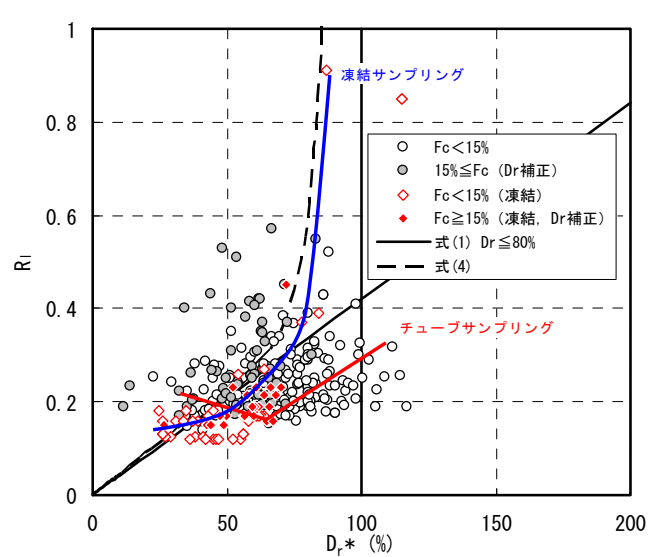

(d) UD ( $D_{r}$ 補正)

図-12 $\quad D_{r}, D_{r}^{*}$ と $R_{l}$ の関係

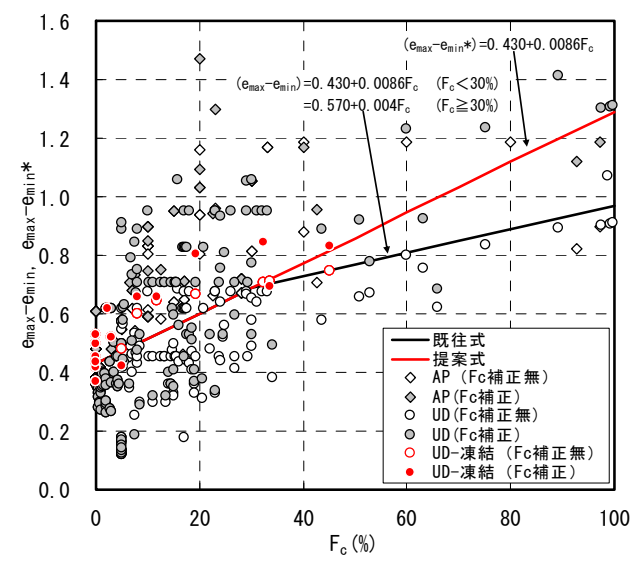

図-13 $F_{c}$ と $\left(e_{\max }-e_{\min }^{*}\right)$ の関係

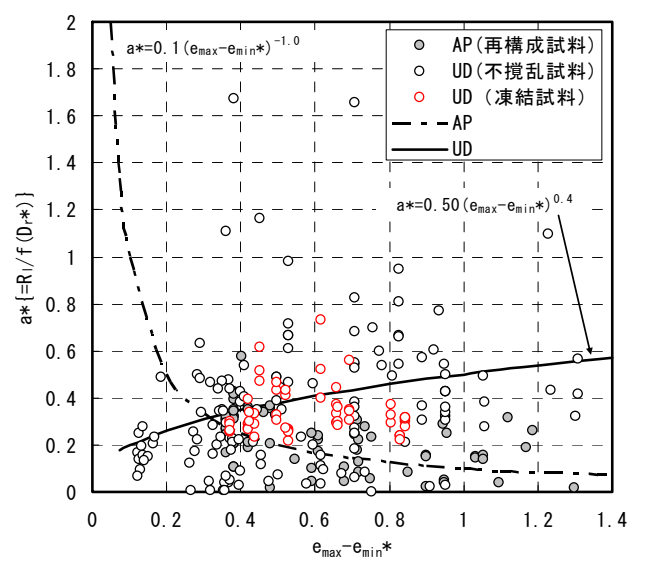

図-14 $\left(e_{m a x}-e_{\min }{ }^{*}\right)$ と $a^{*}$ の関係
間の粒度特性の違い，コンシステンシー特性や細粒分自 体の固結度等の要因によるものと推察される.

また，UDのうち凍結試料に着目すると， $F_{c} \geqq 15 \%$ の プロットについて，中密以上である $D_{r} \geqq 50 \%$ の範囲では， チューブサンプリングの関係に近いものの, 細粒分補正 による $D_{r}^{*}$ とることで，凍結サンプリングの関係とあ る程度調和的となり， $R$ が急増する傾向を良く表してい
る. 一方, $D_{r} \leqq 50 \%$ 範囲では, 凍結サンプリングよりも チューブサンプリングの $R_{l}$ が大きくなっているが, こ れは，比較的緩い地盤のサンプリングでは，試料を密に する傾向にあると考えられる.ただし，細粒分補正をし ない凍結試料の $F_{c}<15 \%$ のプロットを見ると，凍結サン プリングの関係と調和している様子がわかる. 


\section{4. 細粒分が液状化強度に及ぼす影響}

\section{(1) 補正相対密度による液状化強度の評価}

$F_{c} \geqq 15 \%$ を対象に補正した $D_{r}^{*}$ と $R_{l}$ の関係について検 討するにあたり， $\left(e_{\max }-e_{\min }{ }^{*}\right)$ と $F_{c}$ の関係および $\left(e_{\max }\right.$ $-e_{\min }^{*}$ *) と $R_{l}$ の関係について整理した.

まず, $\left(e_{\max }-e_{\min }\right)$ および $\left(e_{\max }-e_{\min }{ }^{*}\right)$ と $F_{c}$ の各関係 について, 図-13 に示す. $\left(e_{\max }-e_{\min }\right)$ と $\left(e_{\max }-e_{\min }{ }^{*}\right)$ の両者を比較すると，AP および凍結試料を含む UD に 拘わらず，補正無しの場合は式(7)と概ね一致するが, $e_{\min }^{*}=0.6$ とした補正有りの場合には， $\left(e_{\max }-e_{\min }^{*}\right)$ は $F_{c}$ に対し，一義的な関係となり，以下に示す式で表され る.

$$
\left(e_{\max }-e_{\min } *\right)=0.430+0.0086 F_{\mathrm{c}}
$$

一方， $D_{r}$ と $R_{l}$ の関係は，式(4)を参考に，次式で表せ ることとする.

$$
R_{l}=a f\left(D_{r}\right)
$$

式(11)より， $F_{c}$ の補正を行った $a^{*}$ と $\left(e_{\max }-e_{\min }{ }^{*}\right)$ の関係 についてまとめ, 図-14 に示す. 図-14 を見ると, プロ ットにばらつきが認められるが，AP と凍結試料を含む $\mathrm{UD}$ で異なる傾向を示している. AP では $\left(e_{\max }-e_{\min }{ }^{*}\right)$ が小さい程 $a^{*}$ は大きく, 一方 UD は逆の傾向を示して おり，これらの関係は，式(12)の様に示すことができる.

$$
a^{*}=b\left(e_{\max }-e_{\min } *\right)^{c}
$$

ただし， $\mathrm{AP} て ゙ は ~(b, c)=(0.05,-2.0), \mathrm{UD}$ に対し $(b, c)=(0.50$, 0.4)を示す. また，式(10)を式(12)に代人することにより， $F_{c}$ と $a^{*}$ 関係を導くことができ，次式で示される.

$$
a^{*}=b\left(0.430+0.0086 F_{c}\right)^{c}
$$

したがって， $R_{l}$ と $D_{r}^{*}$ に関係は，次式のように表される.

$$
R_{l}=b\left(0.430+0.0086 F_{c}\right)^{c} f\left(D_{r} *\right)
$$

なお， $f\left(D_{r}^{*}\right)$ につては，参考文献 のに示されて いる次式を用いた.

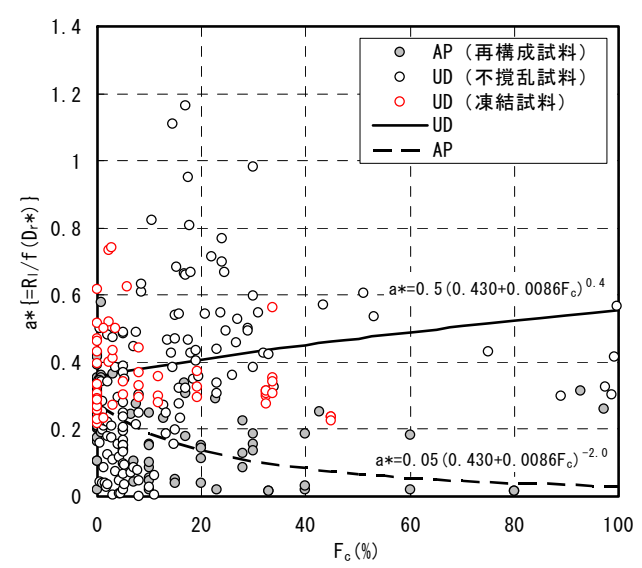

図-15 $\quad F_{c}$ と $a^{*}$ の関係

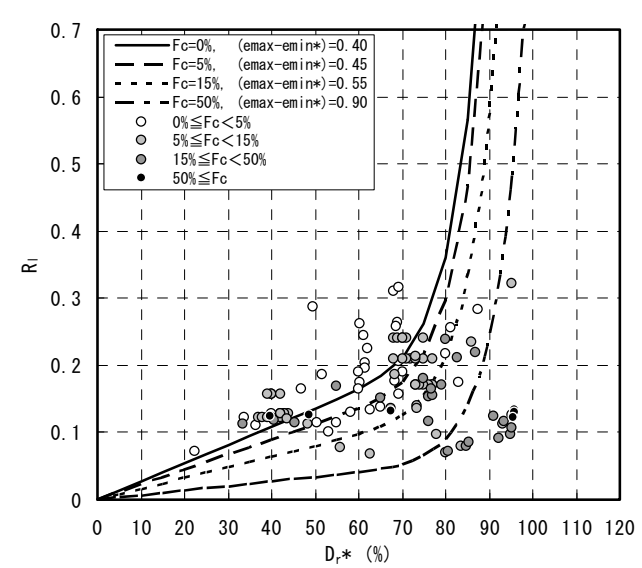

(a) $\mathrm{AP}$ (再構成試料)

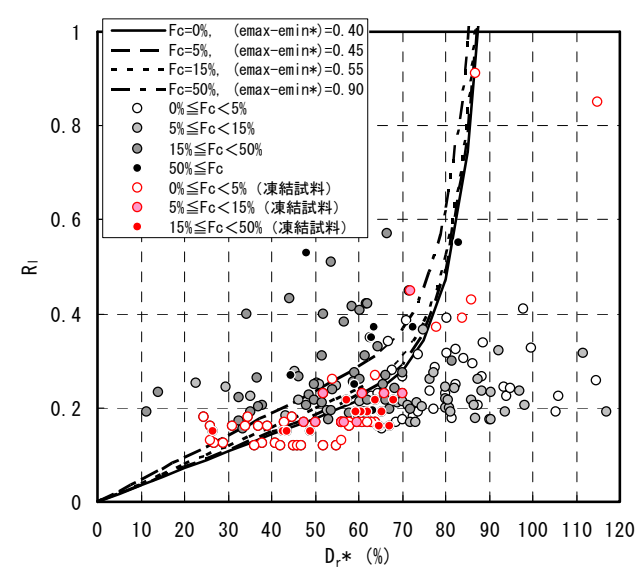

(b) UD（不擋乱試料）

図-16 $D_{r}^{*}$ と $R_{l}$ の関係

$$
f\left(D_{r} *\right)=\frac{D_{r} *}{100}+\left(\frac{D_{r} *}{83.7}\right)^{14}
$$

式(13)および式(14)について，図-15 および図-16 にそ れぞれ示す。図-15 を見ると，特に $F_{C}=20 \%$ 前後におけ るUDのプロットのばらつきが顕著であるが，凍結試料 については式(13)と良く一致している。また，APについ 


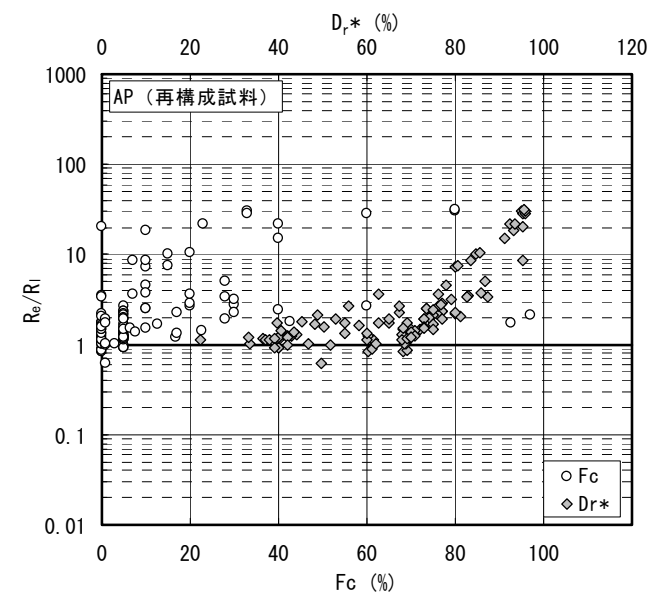

(a) $\mathrm{AP}$ (再構成試料)

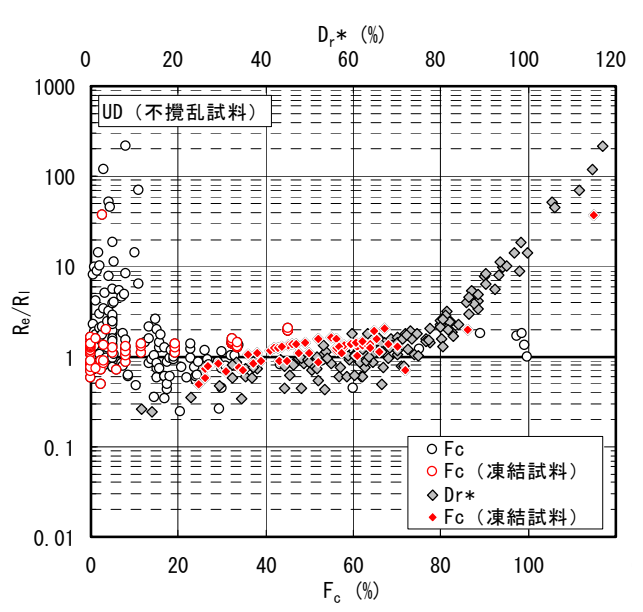

(b) UD (不擋乱試料)

図-17 推定液状化強度の誤差範囲

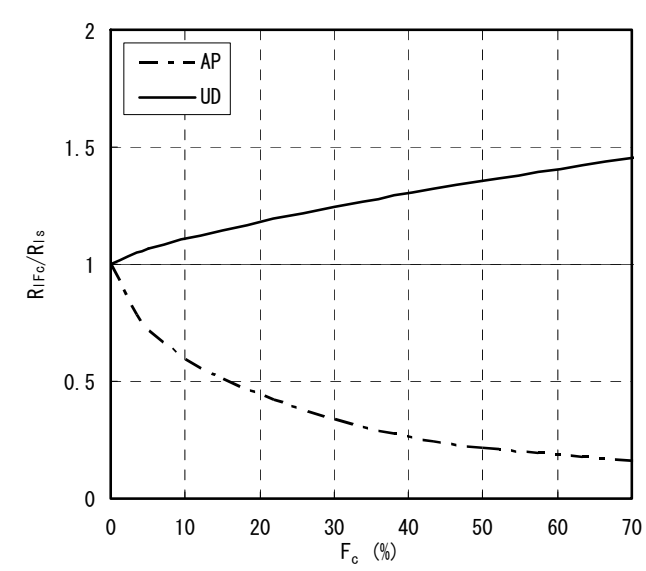

図-18＼cjkstart細粒分による液状化強度増加率

ても式(13)が概ね良好な関係にあることが確認できる.

図-16 における各 $F_{c}$ 毎の $D_{r}^{*}$ と $R_{l}$ の関係を見ると，式 (14)については，AP では， $F_{c}$ の増加に伴い， $R_{l}$ が減少す る傾向を示しているが，試験值と比較的良い相関を示 している．一方，UD では， $F_{c}$ が比較的小さい $15 \%$ 以下 の範囲では，式(14)に対し $R_{l}$ の試験值に大きなばらつき が見られるが，凍結試料は良い一致を見せており，全 般的には式(14)と $R_{l}$ の試験值は調和的であるものと考え られる。

次に，図-16 に示す $R_{l}$ に対する式(14)の精度を確認す るため，同式から得られた液状化強度を $R_{e}$ として，

$\left(R_{l} / R_{l}\right)$ と $F_{c}$ および $D_{r}^{*}$ 関係を図-17 に示す. AP につ いては， $F_{c}$ が 0４0\%の範囲で式(14)は $R_{e}$ を大きく算定 する傾向にあり，いずれも $D_{r}^{*}$ が $80 \%$ 以上に相当してい ることがわかる，一方，UDについては， $F_{c}$ が 10\%以下 における $\left(R_{l} / R_{l}\right)$ のばらつきが大きいが， $D_{r}^{*}$ を確認す ると，AP と同様に $80 \%$ 以上の範囲に相当していること がわかる. しかし, 凍結試料に限ると, $F_{c}$ と $D_{r}^{*}$ に拘わ らず， $\left(R_{l} / R_{l}\right)$ にばらつきが少なく，式(14)と試験值が
調和的であると言える，以上より，式(14)の適用範囲に ついて総合的に判断すると， $F_{c}<15 \%$ の場合に $D_{r}^{*}<80 \%$ であり， $F_{c} \geqq 15 \%$ では $D_{r}^{*}$ の制限は特に無いものと判断 される.

\section{（2）細粒分含有率と液状化強度増加率の関係}

式(14)から得られる $R_{l}$ に関し，図-18 に任意の $F_{c}$ にお ける液状化強度を $R_{\mathrm{ff}}$ として, $F_{c}=0 \%$ における液状化強 度 $R_{l c}$ で除した液状化強度増加率 $\left(R_{\mathrm{lf}} / R_{\mathrm{lc}}\right)$ と $F_{c}$ の関係を 示し, $F_{c} \leqq 70 \%$ の範囲における同一の $D_{r}^{*}$ における $F_{c}$ の 影響について調べた。同図において，APについては, 細粒分が含まれると $R_{\mathrm{If}}$ が減少し, 一方, UD では逆に増 加傾向にある様子が示されている.この両者の相違は， 原位置で採取された試料と再構成試料における構成要 素の粒度特性やマトリクスの固結度，あるいは原位置 における応力履歴の影響等, 様々な要因によるもので あると推察される.

\section{5. まとめ}

地盤調査で得やすい指標を用い，液状化強度を推定す るに当たり，同一条件下における液状化強度の評価が困 難であることから，細粒分含有率が $5 \%$ 以下であるきれ いな砂から低塑性のシルト質砂およびシルトを対象に文 献調査し，低塑性の細粒砂あるいは細粒分を含む砂の相 対密度の補正および液状化強度と補正相対密度の関係に ついて示した. 得られた知見は以下のとおりである.

1) 空中落下法による再構成試料については, 細粒分が 若干含まれることで液状化強度が減少し，ある程度 細粒分含有率が増加することで微増する傾向にあっ た. 一方, 不攪乱試料では, 細粒分含有率の増加に 伴い，液状化強度が増加する傾向を確認した。 
2) 細粒分含有率と骨格間隙比の関係から，特定の細粒 分含有率において物理的性質が変化する. 砂分にあ る程度の細粒分が含まれると, この細粒分含有率を 境に砂粒子同士の接触が減少し, 細粒分の性質が次 第に卓越すると考えられる.

3) 相対密度に対寸る細粒分補正については, $F_{c}>15 \%$ の 範囲で $e_{\text {min }}{ }^{*}=0.6$ と固定することで, $D_{r} \geqq 100 \%$ のデー タであっても, 補正相対密度 $D_{r}^{*}$ ‘゙は $100 \%$ 以内に分 布し，より現実的な值を示した。

4) 既往の試験結果を対象に, 補正間隙比幅をパラメー 夕とした検討を行った結果, ばらつきはやや大きか ったものの, 細粒分含有率が液状化強度に及ぼす影 響度合についての傾向を示すことが出来, 空中落下 法による室内再構成試料の液状化強度は細粒分含有 率の増加に伴い減少し, 不擋乱試料では逆の傾向を 示した. これは, サンプリング方法と採取する試料 の細粒分含有率により, 液状化強度の評価に大きな 影響を及ぼす可能性があることを示唆するものと考 えられる.ただし, 低塑性の試験結果を対象にした 結果であるため, ある程度の塑性を有する試料に対 しては, 別途, 検討の余地があるもとの考えられる.

\section{参考文献}

1) Kuwano, J., Takahara, K., Iimura, H. and Nakazawa, H.: Undrained cyclic and monotonic shear behavior of sandkaolin mixture, 1st International Conference on Earthquake Geotechnical Engineering, Vol.1, pp.165-170, 1995.

2) Ishihara, K.: Simple method of analysis for liquefaction of sand deposits during earthquakes, Soils and Foundations, Vol.17, No.3, pp.1-8, 1973.

3) Tatsuoka, F., Muramatsu, M. and Sasaki, T.: Cyclic undrained stress-strain behavior of dense sands by torsional simple shear test, Soils and Foundations, Vol.22, No.2, pp.55-70, 1982.

4) Tatsuoka, F. , Iwasaki T., Tsuneta, K., Yasuda, S., Hirose, M.,Imai, T. and Konno, M.: A method for estimating under cyclic strength of sandy soils using standard penetration $N$ values, Soils and Foundations, Vol.18, No.3, pp.43-58, 1977.

5) Meyerhof, G.G.: Discussion on research on determining the density of sands by penetration testing, Proc. of 4th International Conference on Soil Mechanics and Foundation Engineering, Vol.1, pp.110, 1957.

6) Tokimatsu, K. and Yoshimi, Y.: Empirical Correlation of Soil Liquefaction Based on SPT $N$-value and Fines Content, Soils and Foundations, Vol.23, No.4, pp.53-74, 1983.

7) 兵頭正幸, 村田秀一, 河原弘明, 川手伸哉, 米村公 貴, 上俊二: 年代効果を有する不擋乱海成粘土の原 位置非排水繰返しせん断強度の評価, 第 30 回土質工 学研究発表会概要集, pp.937-940, 1995.

8) 桑野二郎, Sapkota, B, K., 橋爪秀夫, 高原健吾 : 細 粒分を含む砂の液状化特性, 土と基礎, Vol.41, No.7, pp.23-28, 1993.

9) 桑野二郎, Hwang, S.K. : 細粒分を含む砂の非排水繰 返し三軸試験, 第 24 回土質工学研究発表会, pp.829830, 1989.

10) 足立正樹, 安原一哉: 細粒分を含む砂質土の液状化 特性(1), 第 30 回土質工学研究発表会, pp.907-910, 1995.

11) Chung, K.Y.C. and Womg, I.H.: Liquefaction potential of soils with plastic fines, Proc. of International Conference on Soil Dynamics and Earthquake Engineering, Southampton, pp.887-897, 1982.

12）原田光男, 浦沢義彦, 白井伸一: 細粒分を含む砂に よって造成された海岸埋立地盤の液状化強度特性 （塑性指数と液状化強度の関係），土と基礎，Vol.38, No.6, pp.21-26, 1990.

13) 森伸一郎, 沼田淳紀, 境野典夫, 長谷川昌弘：埋立 地の液状化で生じた噴砂の諸特性，土と基礎，Vol.39, No.2, pp.17-22, 1991.

14) 田中泰雄 : 臨海埋立地の盛土材料の液状化と影響因 子, 土と基礎, Vol.47, No.36, pp33-36, 1999.

15) Cubrinovski, M. and Ishihara, K.: Empirical correlation between SPT N-value and relative density for sandy soils, Soils and Foundations, Vol.39, No.5, pp.61-71, 1999.

16）社団法人地盤工学会 : 土質試験の方法と解説一第一 回改定版一 第 2 編 物理試験 第 8 書 砂の最小 密度・最大密度試験, pp.136-145, 2003.

17) Tsukamoto, Y., Ishihara, K., Nakazawa, H., Kamada, K. and Huang, Y.: Resistance of partly saturated sand to liquefaction with reference to longitudinal and shear wave velocities, Soils and Foundations, Vol.42, No.6, pp.93-104, 2002.

18）竹下貞雄 : 砂の液状化に関する実験的研究, かもが わ出版, 1998.

19) Ishihara, K., Troncoso, J., Kawase, Y. and Takahashi, Y.:Cyclic Strength Characteristics of Tailings Materials, Soils and Foundations, Vol.20, No.4, pp.127-142, 1980.

20) 森伸一郎, 沼田淳紀, 境野典夫, 長谷川昌弘：埋立 地の液状化で生じた噴砂の諸特性, 土と基礎, Vol.39, No.2, pp.17-22, 1991.

21) 桑野二郎, 飯村博忠, 中澤博志, 杉原弘一: 粘土分含有 が砂質土の非排水繰返しせん断特性に及ぼす影響, 粘性土の動的性質に関するシンポジウム発表論文集, pp.143-148, 1995.

22) 中澤博志, 桑野二郎, 杉原弘一, 矢部浩史 : 細粒分を含 む砂の非排水単調及び繰返しせん断特性,第 31 回地盤 工学研究発表会, pp.991-992, 1996.

23）菅野高弘, 中澤博志：液状化対策に関する実物大の 空港施設を用いた実験的研究，港空研資料，No.1195， 2009.

24) Ishihara, K., Tsuchiya, H., Huang, Y. and Kamada, $\mathrm{K}$. :Recent studies on liquefaction resistance of sand effect of saturation, 4th International Conference on Recent Advances in Geotechnical Earthquake Engineering and Soil Dynamics, CD-ROM, 2001.

25) 吉見吉昭：砂の乱さない試料の液状化抵抗 $N$ 值〜 相対密度関係, 土と基礎, Vol.42, No.4, pp.63〜 67, 1994.

26) 中澤博志, 石原研而, 塚本良道, 鎌田敏幸 : 鳥取県 竹内工業団地において不擋乱試料の液状化強度と $\mathrm{P}$ 
波速度の関係，第 58 回土木学会年次学術講演会， III-097, pp.193-194, 2003.

27) 鎌田敏幸, 石原研而, 塚本良道, 中澤博志 : 不完全 飽和状態における不擋乱砂質土の液状化強度特性, 第 58 回土木学会年次学術講演会, III-083, pp.165-166, 2003.

28）建設省土木研究所千葉支所 : 東京湾岸道路地盤耐震 性調査報告書, 1976 .

29) 海老根昭, 中川誠志, 黒原一郎：不カク乱砂の液状 化特性と地震時セン断応力の推定について, 土と基 礎, Vol.26, No.2, pp.19-24, 1978.

30) Tsukamoto, Y., Ishihara, K., Nakazawa, H., Yasuda, S. and Horie, Y.: Soil properties of the deposits in Adapazari from laboratory tests, Proc. of 15 ICSMGE Earthquake Geotechnical Engineering Satellite Conference on Lessons Learned from Recent Strong Earthquakes, pp.275-280, 2001.

31) 亀井祐聡, 森本嚴, 安田進, 清水善久, 小金丸健一, 石田栄介：東京低地における沖積砂質土の粒度特性 と細粒分が液状化強度に及ぼす影響，Soils and Foundations, Vol.42, No.4, pp.11-110, 2002.
32）建設省土木研究所地震防災部振動研究室 : 室内土質 試験に基づく液状化強度一細粒分含有率の影響一, 土木研究所資料，第 2590 号， 1988.

33) 土木学会 : 1983 年日本海中部地震震害調査報告書, 第 4 編 土質・地盤， 1986.

34）善功企, 梅原靖文, 山崎浩之：振動三軸法による液 状化・非液状化地盤の事例解析, 港湾技研資料, No.623, 1988.

35）鬼塚克忠, 吉武茂樹 : 粘土・砂の飽和混合土の圧密 特性，土と基礎，Vol.34, No.7, pp.73-79, 1986.

36) 柴田英明：砂・粘土混合土の締め固め後の構造に関 する一提案, 土と基礎, Vol.34, No.12, pp.17-22, 1986.

37) 社団法人地盤工学会 : 土質試験の方法と解説一第一 回改定版一 第 2 編 物理試験 第 8 書 砂の最小 密度・最大密度試験, pp.136-145, 2003.

38) 沼田淳紀, 染谷昇, 田雜満孝, 國生剛治 : 細粒な土 に対する最小間隙比定義方法の提案, 第 11 回日本地 震工学シンポジウム, pp.665-670, 2002.

(2011.12.12受付, 2012.2.24修正, 2012.3.6受理)

\section{REVISION OF RELATIVE DENSITY AND ESTIMATION OF LIQUEFACTION STRENGTH OF SANDY SOIL WITH FINE CONTENT}

\section{Hiroshi NAKAZAWA and Kenji HARADAH}

It is generally known that liquefaction strength obtained from undrained cyclic triaxial test is influenced by various factors such as relative densities, fine content, grain size distributions and plasticity indexes. However, It is difficult to estimate liquefaction strength for various soil types from same physical properties. In order to estimate the liquefaction strength of various soil types such as silt, silty sands and clean sands, this study showed a method to revice relative density of sandy soil including more than $15 \%$ of fine content and the correlation between reviced relative density and void ratio ranges obtaind from maximum and minimum void ratio. Then, the relationships between void ratio ranges and liquefaction strengths from other studies was considered. As a result, the defference of liquefaction strength between reconstituted and undisturbed samples was recognized from the correlations revised relative density using void ratio ranges and fine content. 